\title{
ゆで過程におけるゆでめん微細構造の観察
}

\author{
佐藤暁子* 松田智明 ${ }^{* *} \cdot$ 伊藤誠治*** ・星野次汪 ${ }^{* * * *}$
}

\section{Scanning Electron Microscopy of Japanese Noodles in Cooking Process}

\author{
Akiko SATO*, Toshiaki MaTSUDA ${ }^{* *}$, Seiji ITO ${ }^{* * *}$ and Tsuguhiro HosHINo**** \\ * Tohoku National Agricultural Experiment Station, 4, Akahira, Morioka-shi, Iwate 020-0123 \\ ** School of Agriculture, Ibaraki University, 3-21-1, Tyuo, Ami-machi, Ibaraki 300-0300 \\ *** Hokuriku National Agricultural Experiment Station, 1-2-1, Inada, Joetsu-shi, Niigata 943-0193 \\ **** Japan International Researh Center for Agricultural Sciences, Tsukuba-shi, Ibaraki 305-8686
}

\begin{abstract}
We investigated the fine structure of surface and cross-sections of Japanese noodles in cooking process with a scanning electron microscope. In the surface of noodles after cooking for $3 \mathrm{~min}$, starch granules were no longer recognizable and small plates and network structure were observed. After cooking for $12 \mathrm{~min}$, the plates turned smaller and the network structure developed among these small plates. After cooking for 18 min lace structure (many filaments were observed) was observed. Near the outer surface of the cross-section of noodles, after cooking for $3 \mathrm{~min}$ starch granules were not recognized and after cooking for $18 \mathrm{~min}$ fine network structure was observed. Near the core of noodles, starch granules and protein matrix were observed clearly after cooking for $3 \mathrm{~min}$. After cooking for $18 \mathrm{~min}$ starch granules were swelled having fine pits while they were recognized in their shape, and protein matrix was buried among starch granules.
\end{abstract}

(Received Jun. 24, 1998 ; Accepted Oct. 26, 1998)

飯米を凍結乾燥した試料を走查型電子顕微鏡で観察す

ると，食味評価の高いコシヒカリでは，炊飯米内部に網 状棈造が多く観察されるのに対し, 粘りの少ない品種で は網状構造が少なく，肧乳細胞やタンパク顆粒が観察さ れるこどかが報告されている. また，炊飯後の時間経過 に伴い, 飯米内部の微細構造が維密化することが食味の 低下に関連していることが示唆された2)。さらに，ゆで めんについても, 走查型電子顕微鏡を用いて, 各種のめ んの表面及び内部構造を比較し，めんの特徽を構造面か ら捉えようとした報告3) 汭がある.

小麦羒で作る日本式めんでは，粘りやかたさが食味評 価の中で重要な項目となっている，官能検查によるめん 適性試験 ${ }^{6}$ の項目の配点は，最近，見直しが行われ んの色が 20 点, めん表面の荒れが 15 点, 食味（匂い .
味) が 15 点, かたさが 10 点, 粘弾性が 25 点,なめらか さが 15 点に配点され，合計 100 点となった. めん表面の 荒れはめん表面状態であり，かたさ，粘弾性及びなめら かさは，食べたときの口内の感触によって決定される物 理的特性に由来するものである. 従って, めん表面及び 内部の構造及び物理的特性は，めん適性評価の中で極め て重要な位膡を占めている. そこで，本報では，ゅでめ んの微細構造の特徵を知る目的で，ゆで時間の経過を 追って試料を作成し，めん表面および割断面の微細構造 を走查型電子顕微鏡を用いて観察した.

$$
\text { 実験方法 }
$$

供試材料は食糧庁より提供された群馬県産の農林 61 号を用いた。この原粒の粗タンパク含量は $8.8 \%$,ビュー

\footnotetext{
*東北農業試験場（宁020-0123 岩手県盛岡市下湢川赤平 4)

** 茨城大学農学部 (T 300-0300 荻城県稲敷郡阿見町中央 3-21-1)

**** 北陸農業試験場（T943-0193 新渴県上越市稲田 1-2-1）

・***国際農林水産業研究センター（テ305-8686 茨城県つくば市大わし 1-2）
} 
ラーテストミルで製粉した $60 \%$ 粉の粗タンパク含量は $7.7 \%$ であった， $60 \%$ 粉 $10 \mathrm{~g}$ を乳鉢に取り，5\% 食塩水 を $4 \mathrm{ml}$ 加え 10 分間乳棒でミキシングし，めん生地を 作った. めん生地を家庭用製めん機（大盛工業，ホーム メンマー)で,めん適性試験( ${ }^{6}$ に準じて, 荒延べ 1 回, 複 合 2 回, 压延 3 回行い, 最終のめん帯の厚さを約 2.5 $\mathrm{mm}$ とし，製めん機に付属した切断機で幅約 $4 \mathrm{~mm}$ のめ ん線とした. $350 \mathrm{ml}$ の水道水 $(\mathrm{pH} \mathrm{5.8)}$ を沸騰させてお き，作成しためん線を涨騰水中でゆでた，予備試験で 18 分でゆで上がりとなったので，ゆで開始直後の3 分，ゆ でめん中心部にやや固さが残る程度の 12 分, ゆで上が りの 18 分後にめんを取り出した. ゆでめんは，プラス チック製ザルにとり，水道水を満たしたボール中で水道 水を流しながら，軽く摜汼し，冷却後に水切りした。 でめんを観察しやすい大きさに切断し，直ちに液体窒素 で冷却したインペンタン中で凍結させた，凍結させた切 片を，真空凍結乾燥機（丘サイェンス，OTD-5 SF 型） を用いて $-60^{\circ} \mathrm{C}$ で乾燥し，表面及び割断面に約 $350 \AA$ の厚さに金蒸着したサンプルを走查型電子顕微鏡 (JSM -T300）で観察した.

\section{実 験 結 果}

\section{1. ゆで過程におけるめん表面の微細構造}

Fig. 1 のゆで前のめん表面では, 直径の大きい 1 次デ ンプン粒 (g) と直径の小さい 2 次デンプン粒 (↔) が明 瞭に識別でき，それらの間を protein matrix (p) が埋 めている構造が認められた. これらの構造は，既報8)の 子実や粉の構造に比べ，表面にデンプン粒が均一に分布 し, protein matrix が識別しにくい特徴があったが, 基 本的には子実や粉と極めて似た構造をしていた。
Fig. 2 のゆで時間 3 分後のめん表面には，すでにデン プン粒の形はどこにも認められず，板状の部分と網状構 造の部分がみられた。

Fig. 3 のゆで時間 12 分後のめん表面では,ゆで時間 3 分後にみられた板状部分が小さく別れ，その間に細かい 網状構造が観察された.

Fig. 4 のゆで時間 18 分後のめん表面では, すきまが 大きく，細い緎維状構造が観察されるレース状の構造が 観察された。

以上のように, ゆでめん表面の観察では, ゆで時間が 進むにつれ，当初観察された板状部分がしだいに細かく なり，その間に細かい網状構造が観察された。 さらにゆ で時間が長くなると，レース状の構造がみられるように なった。

\section{2. ゆで過程におけるめんの割断面の微細構造}

Fig. 5 は，ゆで時間 3 分後の割断面の表層部分で，デ ンブン粒等の形状はすでに認められない.

Fig. 6 は, ゆで時間 3 分後の割断面の表首から約 0.6 $\mathrm{mm}$ の部位（ゆでめんの厚さの約 $1 / 5$ 程度の部位）で, デンプン粒は，その形状をやや残しながらスポンジ状に 観察された。 その間には, protein matrix が白っぱく， 明瞭に認められた。

Fig. 7 は，ゆで時間 3 分後の割断面のめん中央部分 で, 1 次デンプン粒, 2 次デンプン粒, protein matrixな どが明瞭に認められた.

Fig. 8 は, ゆで時間 18 分後の割断面の表層部分で, 極 めて細かい網状の構造が認められた。

Fig. 9 は，ゆで時間 18 分後の割断面の表層から約 0.6 $\mathrm{mm}$ の部分で，小さな穴をあつ構造が観察され，デンプ ン粒の形状ははっきり識別できず, protein matrix も存

Explanation of figures (Fig. 1 Fig. 10)

Fig. 1 Surface of noodles before cooking

Fig. 2 Surface of noodles after cooking for $3 \mathrm{~min}$

Fig. 3 Surface of noodles after cooking for $12 \mathrm{~min}$

Fig. 4 Surface of noodles after cooking for $18 \mathrm{~min}$

Fig. 5 Near the outer surface of the cross-section of noodles after cooking for $3 \mathrm{~min}$

Fig. 6 The part of $0.6 \mathrm{~mm}$ from the outer surface of the cross-section of noodles after cooking for $3 \mathrm{~min}$

Fig. 7 Near the core of noodles after cooking for $3 \mathrm{~min}$

Fig. 8 Near the outer surface of the cross-section of noodles after cooking for $18 \mathrm{~min}$

Fig. 9 The part of $0.6 \mathrm{~mm}$ from the outer surface of the cross-section of noodles after cooking for $18 \mathrm{~min}$

Fig. 10 Near the core of noodles after cooking for $18 \mathrm{~min}$

Abbreviations used in figures :

g, primary starch granule ; $\rightarrow$, secondary starch granule ; p, protein matrix

Black bars in photographs indicate $10 \mu \mathrm{m}$. 


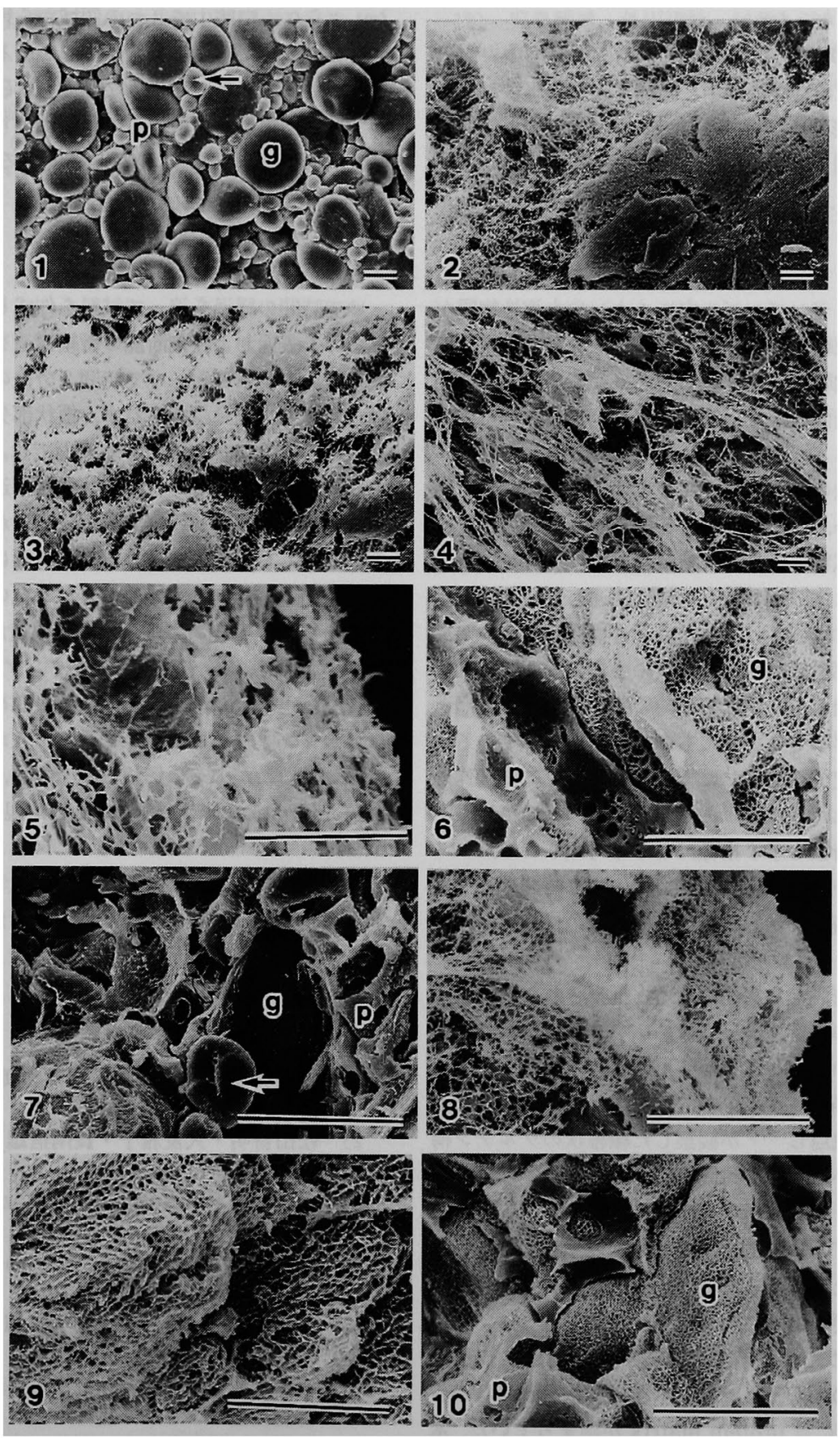


在を識別できなかった。

Fig. 10 は，ゆで時間 18 分後の割断面のめん中央部分 で，デンプン粒にはきめ細かく微細な穴が観察され，大 きさはかなり膨らんでいるが，その形状はほ幟別で き，それらの間には protein matrix が詰まっているよ うに観察された.

\section{考察}

相原ら”は，デンプンゲル中にイオンや水溶性物質が 存在すると，凍結したときに水結晶核となってゲル中の 水分が氷結し微細な穴状構造ができるとし，新米にはデ ンプン眝留体表面に小さい穴状の構造が観察されるが， 古米にはほとんど観察されないこと報告した。これは， 新米が穴状構造の生成原因となるイオンや水溶性物質を 多く含み，かつ，炊飯時に水分を取り込みやすいことを 示しており，試料作成中の涷結乾燥過程にできた構造で あるが炊飯中に生じた現象と密接に関連していること示 した．また，木村ら ${ }^{10)}$ は，ゆでめんの構造観察の中で， ゆでめん周边部に観察される多数の小穴は，ゆでたとき に侵入する多量の水分が，観察時の東結により，氷晶と なり，それが昇華してできたものであると述べている。 従って，本研究で観察された構造す，凍結・乾燥操作の 結果, 形成された構造ではあるが，ゆでめんの構造やデ ンプンゲルの特徽を示す指標になると考えられる.

本研究のゆでめん表面の観察では，ゆで時間の経過に 伴い，板状構造，網状構造及びレース状の構造等が観察 された.このうち，板状部分については，その形状から， デンプン粒が膨潤した構造であると推察された．網状構 造とレース状の構造については，デンプン粒が膨潤し形 成されたものか, グルテンから形成されたすのか判断で きない．ゆで時間 18 分後に観察されたレース状の構造

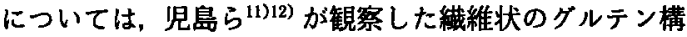
造と良く似ている．ゆで時間が長くなるとゆでめん表面 の膨潤したデンプンが湯中に溶けだし，デンプン粒を取 り囲んでいたグルテン構造がゆでめん表面に観察される ようになったとも考えられるが, 詳しくは染色 ${ }^{13)}$ 等によ り識別する必要がある.

また，ゆでめんの表層部は微細な網状構造が観察さ れ，ゆでめんの中心部はデンプン粒の形状を残しながら 糊化し，その間には protein matrix が詰まっていた. 木 村ら ${ }^{10)}$ は,ゆでめんのデンプン粒の膨潤状態は，めんの 部位によって異なり，周辺部のデンプンは膨潤が著しく 粒の原形が認められないが，中央部のデンプンは表層部 のみ膨潤し，内部は緻密な構造をむつことを明らかにし

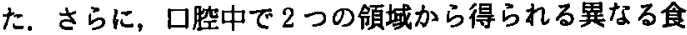
感をほぼ同時に感ずるときにこしがあるという感覚が生 じるのではないか(14) と述べている. 本研究の観察結果も ゆでめんの構造が表首からの距離により異なることを示 しており，木村ら ${ }^{10)}$ の観察と一致するものと考えられ る.

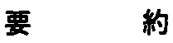

ゆで時間の経過を追って試料を作成し，ゆで過程にお けるめん表面および割断面の微細構造を走查型電子顥微 鏡を用いて観察した．ゆで時間 3 分後のゆでめん表面に は，デンプン粒は認められず，板状部分と網状構造が観 察された. 12 分後のゆでめん表面では，細かい板状部分 と，その間を埋めている細かい網状構造が観察された。 さらに, 18 分後には, 細い繊維状構造から成るレース状 の構造がみられた．ゆでめんの割断面は，表層部では, ゆで時間 3 分後にはすでにデンプン粒の形状は識別でき ず, 18 分後には極めて細かい網状構造が観察された. め んの中心部は, 3 分後では, 1 次デンプン粒, 2 次デンプ ン粒, protein matrixなどが明睹に認められた. 18 分後 にはデンプン粒はきめ細かく微細な穴が空き，かなり膨 らんではいたが, その形状は認識でき，それらの間には protein matrix がつまっているのが観察された。

本研究を実施するにあたり，茨城大学農学部作物学研 究室の皆様には，ご指導，ご協力をいただいた．皆様に 厚くお礼申し上げる.

\section{文献}

1）松田智明・長南信雄・土屋哲郎：日作紀 58 (別 2), 261 (1989).

2）松田智明・大友雅子・長南信雄 : 茨城大学農学術 報，38，1（1990）。

3) Он, N.H., P.A. SEIB, C.W. DEYOE and A.b. WARD : Cereal Chem. 62, 431 (1985).

4) Dexter, J.E., Matsuo, R.R. and DronzeK, B.L. : Cereal Chem. 56, 202 (1979).

5) Moss, R., P.J. Gore and I.C. Murray : Food microstructure 6, 63 (1987).

6）農林水産省食品総合研究所 : 小麦の品質評価法一 官能検查によるめん適性一，4（1985）.

7）食糧庁 : 国内産小麦の評価に関する研究会報告書 (1997).

8）佐藤暁子・小柳敦史・和田道宏・松田智明：日作 紀, 62, 183 (1993)

9）相原茂夫・梅木加奈恵・柴田克己・桶笠隆彦・渡 
辺 清・広瀬正明 : 日本栄養・食糧学会誌，46, 77 (1993).

10）木村利昭・藤原正弘 - 小川敬子 · 藤野良子 - 相良 康重・神武正信・井筒 雅・中島一郎：農化， 70, 1343 (1996).

11）肾島雅博・村瀬 誠・戸谷精一・杉本勝之：日食 工誌, 39, 471 (1992).
12）児島雅博 - 外川達秋 - 村瀬 誠 ·户谷精一・杉本 勝之: 日食科工誌，42，899 (1995).

13）小田聞多：めんの本，食品産業新聞社，表紙及び 巻頭 (1980).

14）木村利昭：食品工業，4.30，42 (1997).

（平成 10 年 6 月 24 日受付, 平成 10 年 10 月 26 日受理） 